\title{
National Federal Fleet Loaner Program Interim Status Report
}

\author{
J. E. Francfort
}

October 2000

Idaho National Engineering and Environmental Laboratory Bechtel BWXT Idaho, LLC 
INEEL/EXT-2000-01357

\title{
National Federal Fleet Loaner Program Interim Status Report
}

\author{
Jim Francfort
}

Published October 2000

Idaho National Engineering and Environmental Laboratory Automotive Systems and Technology Department Idaho Falls, Idaho 83415

Prepared for the

U.S. Department of Energy

Assistant Secretary for

Energy Efficiency and Renewable Energy

Under DOE Idaho Operations Office

Contract DE-AC07-99ID13727 


\section{EXECUTIVE SUMMARY}

The goal of the U.S. Department of Energy's (DOE) Loaner Program is to increase the awareness, deployment, and use of electric vehicles (EVs) in Federal fleets. The Loaner Program accomplishes this by providing free EVs to Federal fleets on a loaner basis, generally for 1 or 2 months. The Program partners DOE with six electric utilities, with DOE providing financial support and some leads on Federal fleets interested in obtaining EVs. The utilities obtain the vehicles, identify candidate loaner fleets, loan the vehicles, provide temporary charging infrastructure, provide overall support to participating Federal fleets, and support fleets with their leasing decisions.

While the utilities have not had the success initially envisioned by themselves, DOE, the Edison Electric Institute, and the Electric Vehicle Association of the Americas, the utilities can not be faulted for their efforts, as they are not the entity that makes the ultimate lease or no-lease decision. Some external groups have suggested to DOE that they direct other federal agencies to change their processes to make loaning vehicles easier; this is simply not within the power of DOE. By law, a certain percentage of all new vehicle acquisitions are supposed to be alternative fuel vehicles (AFV); however, with no enforcement, the federal agencies are not compelled to lease AFVs such as electric vehicles.

Common sense dictates that the level of concentration of Federal fleets within a utility's service territory must influence a utility's ability to place greater numbers of loaner vehicles. This proved true in practice as the greater Washington D.C. utility (Potomac Electric Power Company) had the most success in generating leases (15). Minimizing bureaucratic input (both Federal Agency and utility) appears to increase the likelihood of successfully loaning vehicles. There are pockets of risk-takers within fleets that are willing to adopt new technology vehicles; however, bureaucracy does not encourage such behavior.

Forty-six vehicle loans took place, allowing at least 178 Federal employees to test drive the EVs. The amount of exposure was significant; each driver was able to gain an average of over 200 miles of EV experience. However, the cost to obtain this experience was not inconsequential. It cost DOE about $\$ 1,200$ for each driver (about $\$ 5$ per loaner mile), but this may not be unreasonable when one considers that temporary charging infrastructure had to be installed, the vehicles delivered and returned, and that each driver receives at least brief training.

Since the ultimate goal is to increase the deployment and use of EVs by Federal fleets, this should be the criteria to measure the success of the Program. Fifteen vehicle leases can be directly credited to the Program, with another seven leases probably resulting from Loaner

Program activities. It has cost DOE about $\$ 9,800$ for each electric vehicle lease generated by the Loaner Program. If the utilities' contributions have been about equal to DOE's costs, the Loaner Program has cost a combined total of $\$ 19,500$ for each lease generated.

This report discusses the Loaner Program status as of August 2000. 


\section{CONTENTS}

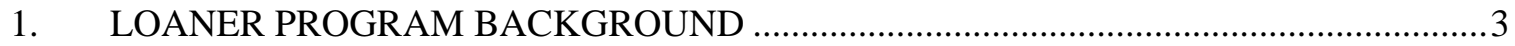

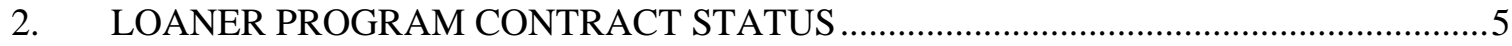

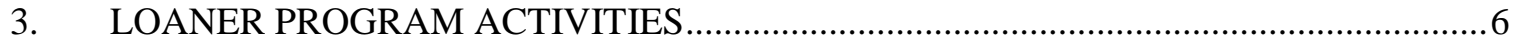

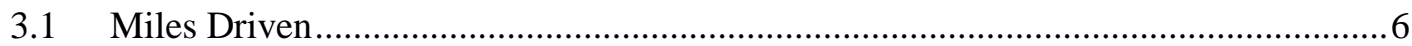

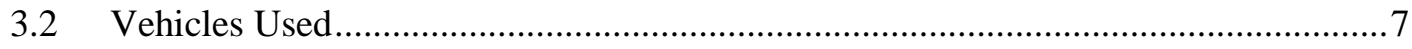

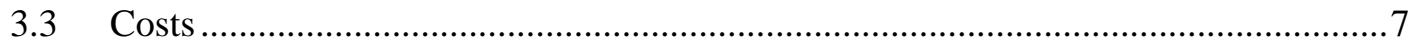

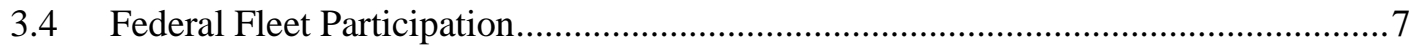

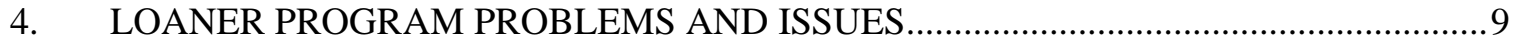

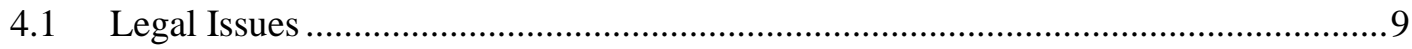

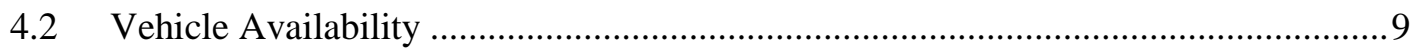

4.3 Driver Surveys and Utility Comments ......................................................... 10

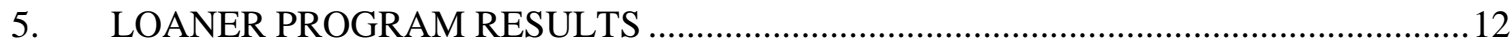

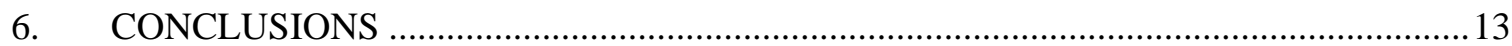




\section{National Federal Fleet Loaner Program Interim Status Report}

\section{LOANER PROGRAM BACKGROUND}

The National Federal Fleet Loaner Program is an U.S. Department of Energy (DOE) sponsored program (Office of Transportation Technologies) that encourages the deployment and use of electric vehicles (EV) by Federal fleets. The Loaner Program consists of partnerships between DOE and six electric utilities. The Loaner Program concept developed from discussions held between DOE, the Edison Electric Institute, and the Electric Vehicle Association of the Americas. These discussions led to a formal DOE solicitation process that resulted in contract agreements between DOE and the six utilities. DOE's six utility partners are:

- $\quad$ Boston Edison

- Georgia Power

- $\quad$ Potomac Electric Power Company (PEPCO)

- $\quad$ San Diego Gas and Electric (SDGE)

- $\quad$ Southern California Edison (SCE)

- Virginia Power.

The Loaner Program is managed as part of DOE's Field Operations Program. The Field Operations Program goals include evaluating electric and other advanced technology vehicles in real-world applications and environments and increasing the awareness, acceptance, and use of electric and advanced technology vehicles. Loaner Program activities support these goals by increasing the awareness, deployment, and use of electric vehicles by Federal fleets. The Idaho National Engineering and Environmental Laboratory has the responsibility for the day-to-day functions, contracting, and reporting for the Loaner Program.

In general terms, the DOE awarded contracts to each of the six utilities to obtain EVs and loan them to interested Federal fleets within each of their six respective service territories. The number and models of EVs that each utility leased varied somewhat, but generally consisted of five EVs each. EV models included mostly Chevrolet S-10s, Ford Rangers, and Toyota RAV4s.

The utilities' responsibilities include:

- Identifying Federal fleets that are candidates for participating in the Loaner Program

- $\quad$ Contacting the Federal fleets

- $\quad$ Obtaining the loaner EVs

- $\quad$ Providing the loaner EVs to the Federal fleets 
- $\quad$ Educating the potential Federal fleets about the capabilities of EVs

- Installing temporary charging infrastructure

- $\quad$ Gauging the acceptance of the EVs by the Federal employees driving the EVs

- $\quad$ Supporting the Federal fleets if they decide to pursue leasing EVs on a permanent basis.

If a Federal fleet decides to pursue leasing an EV, DOE provides one-half of the incremental cost of the vehicle and the utilities would provide additional support to the Federal fleets, including:

- Helping Federal fleets match the capabilities of vehicles with their requirements

- Helping install permanent charging infrastructure

- Helping with the EV acquisition process. 


\section{LOANER PROGRAM CONTRACT STATUS}

PEPCO was DOE's initial Loaner Program partner, providing loaner vehicles for approximately 6 months before contracts were signed with the other utilities during the spring of 1999. All of the original DOE and utility agreements were for 1 year and each utility provided various types of support. Some of this support included providing administrative and management support, installing infrastructure, and providing loaner vehicles.

The PEPCO agreement expired during the fall of 1999, however, PEPCO continued to loan EVs to Federal fleets on its own through the end of 1999. The contracts for the other five utilities ran through the end of April 2000; SDGE and SCE requested and received from DOE-Idaho (DOE contracting office) no-additional-cost contract extensions to continue their Loaner Program Activities. The contract status for each utility is as follows:

- $\quad$ Boston Edison

Contract ended

- Georgia Power

Contract ended

- $\quad$ PEPCO

Contract ended

- $\quad$ SDGE

Additional performance period

- $\quad$ SCE

Additional performance period

- Virginia Power

Contract ended

Several factors influenced the utilities' decisions not to request contract extensions. Some of these factors include insurance and liability, vehicle availability, bureaucratic inertia (both utility and Federal), ease of installing charging infrastructure, vehicle recalls, difficulties identifying candidate Federal fleets, and the rate at which vehicles were successfully loaned. 


\section{LOANER PROGRAM ACTIVITIES}

\subsection{Miles Driven}

The utilities made 46 vehicle loans (Table 1) to the various federal fleets. Except for one instance, all of the vehicle loans consisted of loaning a single vehicle to a single federal fleet, generally for a period of 2 months. More than 178 federal employees took advantage of the opportunity to drive the vehicles. Unlike typical ride-n-drives at industry conferences where a driver simply drives an EV around the block, the Loaner Program allowed the drivers to drive the vehicles for extended periods of time, gaining significant EV knowledge.

Table 1. Total Loaner Program activity. ${ }^{\text {a }}$

\begin{tabular}{lccc}
\hline Utility & No. of Vehicles & No. of Drivers & Miles \\
\hline Boston Edison & 8 & 35 & 6,065 \\
Georgia Power & 10 & 54 & 1,861 \\
Potomac Electric Power Company & 19 & 45 & 17,821 \\
San Diego Gas and Electric & 2 & 4 & \\
Southern California Edison & 2 & 4 & 1,118 \\
Virginia Power & 5 & $36+$ & \\
Totals & 46 & $178+$ & 26,865 \\
\hline
\end{tabular}

a. The number of vehicles is the number of vehicle loans made by each utility. The number of drivers is the number of federal employees that took advantage of the Loaner Program and drove one or more of the loaner vehicles. The miles is the total miles the federal employees drove the loaner vehicles (not all of the miles were reported).

While 26,865 Loaner Program miles were recorded, not all of the utilities collected the number of miles each vehicle was driven during every loan and the number of drivers. However, enough data was collected to make the following observations about the Loaner Program activities and success, with only a minimal amount of assumptions employed.

For those utilities reporting the miles driven and number of drivers, each of the 122 drivers drove an EV an average of 217 miles. Four of the utilities (Appendix A, Tables A1 through A6) reported the number of drivers and miles. Their average number of miles per driver ranged from 28 miles (Georgia Power) to 614 miles (PEPCO). The other utilities reported average number of miles per driver of 173 miles (Boston Edison) and 280 miles (SCE).

For those utilities reporting miles driven and the number of vehicle loans (24), the federal fleets drove each vehicle an average of 1,119 miles. Four utilities (Appendix Tables A1 through A6) reported the number of vehicle loans and miles, and their average mile per vehicle loan included 186 miles (Georgia Power), 758 miles (Boston Edison), 1,118 miles (SCE), and 3,654 miles (PEPCO). 
When the average miles driven per driver is extrapolated to the total number of drivers (178), the total number of miles driven during the Loaner Program would be approximately 39,000 miles. Similarly, when the average miles driven per vehicle loan is extrapolated to the total number of vehicle loans (46), the total number of miles driven during the Loaner Program would be approximately 50,000 miles. If the average of these two totals is used, one can assume that the Loaner Program participants gained 45,000 miles of EV exposure.

\subsection{Vehicles Used}

Each utility proposed to DOE what vehicle models they would offer as loaner vehicles to the federal Fleets. Not all vehicles models were loaned out by each of the utilities. The actual models loaned were not tracked. The vehicle models each utility made available as a loaner vehicle is listed in Table 2.

Table 2. Vehicle models made available by the electric utilities as loaner vehicles.

\begin{tabular}{ll}
\hline Federal Fleet & Vehicle Models \\
\hline Boston Edison & 1 Chevrolet S-10s, 1 Solectria Force, 1 Ford Ranger \\
Georgia Power & 2 Ford Rangers (1 NiMH \& 1 Lead Acid), 1 Chevrolet S-10, \\
& 1 General Motors EV1 \\
Potomac Electric Power & 5 Ford Rangers \\
Company & \\
San Diego Gas and Electric & $\begin{array}{l}\text { Toyota RAV4, Ford Ranger, Chevrolet S-10, Chrysler EPIC, } \\
\text { Honda EVPlus (1 each) }\end{array}$ \\
Southern California Edison & 2 Chevrolet S-10s, 1 Chrysler EPIC, 2 Ford Rangers, \\
& 3 Toyota RAV4s, 1 Honda EVPlus, 1 General Motors EV1 \\
Virginia Power & 5 Chevrolet S-10s \\
\hline
\end{tabular}

\subsection{Costs}

The definitive costs for providing 45,000 miles of EV experience to over 178 participants is not yet known (not all of the final invoices have been received). However, using estimated costs invoiced as of August 2000 (\$215K), the Loaner Program costs can be compared to the Loaner Program activities. The Loaner Program has cost DOE slightly over $\$ 1,200$ per driver, or about $\$ 5$ per loaner mile. There is no information readily available that documents the costs of a similar type of program. In fact, such a National Program has never been conducted previously, and the cost of ride-n-drives is not known.

\subsection{Federal Fleet Participation}

Thirty-nine federal fleets took advantage of the Loaner Program. Often, more than one fleet from the same agency or department participated. (A complete breakdown, by utility and federal fleet, is available in Tables A1-A6). Whether measured by the number of miles driven, the number of drivers, or the number of vehicle loans, Department of Interior fleets took the greatest advantage of opportunities to use the loaner vehicles. This group and its 60 drivers drove the vehicles 13,147 miles (see Table 3, National Parks/Wildlife Refuges/Battlefields/Fish and Wildlife/Seashores/DOI). The Environmental Protection Agency also made significant use 
of the Loaner Vehicles, especially when measured by the number of miles driven and number of drivers. The United States Army, within Virginia Power's service territory, had the second highest number of Loaner Program participants when measured by the number of drivers (Appendix, Table A6).

Many federal fleets are not able to participate in the Loaner Program since they are not located within the utilities' service territories. For instance, none of DOE's large laboratories are located within any of the service territories, so the only DOE fleets that were able to participate in the Loaner Program were the Germantown and Headquarters fleets. It should be noted that federal fleets other than the U.S. Postal Service have ordered 176 EVs with incremental funding support from DOE as directed by Executive Order 13031 (Federal Alternative Fueled Vehicle Leadership). DOE and its laboratories have ordered $23 \%$ of the 176 vehicles. The U.S. Postal Service has placed an order for 500 electric light-duty delivery vehicles. This vehicle uses the electric Ford Ranger components. Delivery is scheduled to start in earnest during the last few months of calendar year 2000.

Table 3. Federal fleets that took advantage of the Loaner Program. ${ }^{\text {a }}$

\begin{tabular}{lccr}
\hline Federal Fleet & No. of Vehicles & No. of Drivers & Miles \\
\hline Architect of the Capitol & 1 & 1 & \\
Army & 5 & $36+$ & 1,118 \\
Border Patrol & 1 & 4 & 360 \\
Coast Guard & 1 & 4 & 2,904 \\
Department of Energy & 2 & 5 & 1,400 \\
Department of Transportation & 3 & 13 & 4,411 \\
Environmental Protection Agency & 7 & 27 & 157 \\
Federal Highway Administration & 1 & 10 & 3,368 \\
General Services Administration & 1 & 4 & 1 \\
Marines & 1 & 1 & 13,147 \\
National Institute of Health & 1 & 1 & \\
National Institute of Standards \& Technology & 1 & 60 & \\
National Parks/Wildlife Refuges/Battlefields & 13 & 1 & \\
/Fish and Wildlife/Seashores/DOI & & 4 & \\
National Security Agency & 1 & 1 & \\
Navy & 3 & 4 & \\
Senate & 1 & 1 & \\
Smithsonian & 1 & & \\
White House & 1 & & \\
\hline a. The groups may include several federal fleets in different locations. Mileage was not reported by all utilities \\
for all federal fleets. (DOI - Department of the Interior) & & & \\
\hline
\end{tabular}




\section{LOANER PROGRAM PROBLEMS AND ISSUES}

\subsection{Legal Issues}

When looking at the activities by each utility, either by number of vehicles loaned, drivers, or miles, it is evident that PEPCO had the most success at loaning vehicles. The concentration of federal agencies and fleets in PEPCO's service territory, in and near the District of Columbia, would lead one to expect that PEPCO would loan the most vehicles of all the utilities. In addition, PEPCO did not have a burdensome legal leasing process, and this appears to be extremely important if loans were to occur. Each utility was free to design their Loaner Program in a method that best fit their corporate structure, the structure of the federal fleets in their service territory, and other constraints such as state Public Utility Commission regulations. PEPCO previously had in place an agreement with the General Services Administration (GSA) that allowed PEPCO to work with the various fleets. None of the other utilities had this advantage. Several of the utilities reported severe delays and problems with the issue of who would assume liability for the vehicles if an accident occurred. However, PEPCO would generally loan the vehicles with a simple three-page written agreement, assuming that the vehicle loans could occur under the umbrella of the GSA Agreement.

It became apparent that legal issues often seriously delayed some loans, and completely canceled other loans when agreement could not be reached. The largest problem was over the issue of whom would be liable if a vehicle were involved in an accident. Some of the utilities wanted the federal fleets to take out insurance, but the federal fleets are self-insuring and would not indemnify the utilities. Sometimes, so much time was required for the federal and utility lawyers to come to agreement that the fleet managers and utility Loaner Program manager would give up trying to place a vehicle.

\subsection{Vehicle Availability}

All of the major original equipment manufacturers (OEM) have provided EVs in limited numbers over the last few years. Some of the OEMs have limited their products to California, or limited their products with advanced batteries to California, and were only available in very limited numbers. Because of limited vehicle availability, some utilities decided to end their own local loaner programs and this affected their participation in the Federal Loaner Program. There have been suggestions (rumors) that when the OEMs vehicles come to the end of their current 3year leases, they will be reconditioned (if necessary) and released. However, nothing formal has been announced or implemented. The following sections describe the current availability of EVs, as the author believes to be true. Most of the OEMs have future plans for deploying smaller EVs (such as the Ford Th!nk City), or hybrids, or both.

Chrysler - Chrysler made available approximately 150 electric EPIC minivans, mostly in California. It is believed that all 150 have been leased and no more EPICs will be available.

Ford - The Ford Ranger suffered some of the same earlier problems that the Chevrolet S10 did (see next section) in that the Ranger's first lead-acid batteries had range problems. However, Ford appears to have worked with a new lead-acid battery supplier to ensure the batteries are manufactured to the required specifications. Unfortunately, the time that was 
required to correct the lead acid battery and other problems resulted in some fleets having to wait for 6 months or longer for their Rangers. Ford probably leased somewhere between 300 and 400 vehicles during 1999. It is believed that Ford will be the only OEM providing pure EVs during 2000 (The EV1 may still be available but it is not usually considered as a fleet vehicle). They will probably build about 600 EV Rangers during 2000, and perhaps 200 are already allocated for prior orders. This leaves about 400 EV Rangers available for leasing during 2000. The leadacid Rangers are available nationally, provided an EV-certified warranty provider (generally a Ford dealer) is available.

General Motors - GM provided two vehicle choices, the EV1 sports coupe and the S-10 pickup. The EV1, as a two-seat coupe, did not meet the mission requirements of most fleets, and it was only available in a few states. The S-10 provided excellent driving performance, but its earliest versions used a lead-acid battery that performed poorly and the vehicle did not sell. The S-10 is no longer available. When General Motors recalled some of the S-10s and EV1s for charger port problems (potential fire hazards), Virginia Power had to end their Loaner Program because of their dependence on the S-10s. Virginia Power was not only faced with the prospect of not having vehicles available; they also had to face the issue of their own corporate liability if a fire occurred.

Honda - Honda leased approximately 300 EV Plus electrics in California. They are not making any more vehicles available. Honda was unique among the OEMs, as they targeted the general public for leasing their EVPlus while the other OEMs targeted public and private fleets for vehicle leasing.

Nissan - Nissan made available about 50 of their lithium EVs to fleets in California. A large deployment was never initiated, nor is it believed that one is planned.

Toyota - Toyota's electric RAV4 is a very popular vehicle with those that have them. Southern California Edison has about 250 RAV4s in their fleet. While the vehicles were primarily available in California, they have also been leased in other parts of the country. Probably somewhere around 500 RAV4s have been leased nationally. However, no more RAV4s are likely to be built and leased.

\subsection{Driver Surveys and Utility Comments}

The six utilities provided quarterly reports to the INEEL. These reports have been used to compile the information in this Interim Status Report. In addition, the utilities were asked to provide their comments and opinions about the Loaner Program. They have provided this information and it is available in Appendix A. The specific areas that the utilities reported on are as follows:

- $\quad$ Federal fleets gave several reasons for not leasing EVs (Table A7).

- $\quad$ Federal fleet drivers gave their reactions after driving the loaner vehicles (Table A8).

- The utilities encountered a variety of obstacles when trying to loan EVs to the federal fleets (Table A9). 
- $\quad$ Some of the utilities provided comments about the vehicles leased for the Loaner Program (Table A10).

The author of this Interim Status Report has generally not connected specific comments to specific utilities; this has been intentional. The utilities have been very frank about the problems they encountered, and they should not be criticized because of this frankness and trust. However, the comments below by Boston Edison and Southern California Edison provide good insight into some of the problems they dealt with. The comments are not repeated word-for-word, as the author has altered some of the comments to better put them into context.

\subsubsection{Boston Edison}

All the drivers expressed how much they liked the performance of the electric vehicles, and it is expected that at least one of the first three agencies to borrow a vehicle will try to buy or lease an EV. Boston Edison is loaning the vehicles out for longer than 30 days, because agency heads have requested this. It gives the agency a better opportunity to fully evaluate the performance in real-world conditions. Also, the time to install the infrastructure has been lengthy, and it makes more sense to let the agencies keep the vehicle longer because of this.

While feedback has been varied, most of the users are very impressed with these vehicles. Boston Edison has had several agencies turn them down due to the simple indemnification Boston Edison has required. Even when Boston Edison is willing to negotiate for a simple TORT agreement instead, sometimes the federal agency just does not want to be bothered. Boston Edison is having about a 50\% success rate in loaning vehicles out. All in all, this is probably not too bad. The U.S. Fish and Wildlife Service is in line to loan two vehicles from Boston Edison, but their Washington office is slow to agree to simple contract language so Boston Edison can formally start the program. This has been the biggest programmatic problem. For this reason, Boston Edison has been extending the current loans up to 120 days in some cases so that all vehicles are being used during the waiting period. This program is rewarding in many ways, especially when the reaction is positive from all drivers.

\subsubsection{Southern California Edison}

Even while the loan agreement contracts are being reviewed, Southern California Edison has been working closely with the federal representatives to evaluate their existing light-duty fleet, and identify vehicles that could be replaced with electric vehicles. Southern California Edison has recently conducted an Electric Vehicle Workshop that educated federal personnel on the benefits of including electric vehicles into their fleet mix. While Southern California Edison's original estimate as to the number of what manhours that would be expended to complete a loan were based on their past experience in dealing with their commercial customers in their Electric Vehicle Trials Program, Southern California Edison has found this to be an underestimate in dealing with federal agencies. This was a lesson learned for Southern California Edison in dealing with federal fleets. 


\section{LOANER PROGRAM RESULTS}

DOE's Incremental Funding Program (also managed by the INEEL) provides one-half the incremental cost to any federal fleet that leases a light-duty, highway-capable EV. The Incremental Funding Program has provided incremental funding to 25 Federal fleets, in support of leasing 175 EVs. (Agencies have been leasing vehicles either through the GSA or directly from Ford and Chrysler; DOE provides incremental funding support through GSA or directly to the leasing agencies if they lease directly from the manufacturer). This set of 175 leases is used to identify leases generated by the Loaner Program. The success of the Loaner Program should be judged by how many EV leases are generated, as this is the ultimate goal of the Loaner Program. While increasing awareness about EVs is also a goal, this is a difficult parameter to definitively measure; and, besides, increasing awareness is also ultimately intended to increase leasing rates.

The number of leased EVs that can be directly credited as resulting from Loaner Program activities is probably 15 . These 15 EVs were all leased in the PEPCO service territory after PEPCO provided loaner vehicles. It should also be acknowledged that PEPCO has subleased Rangers to support the deployment of EVs to Federal fleets. Not all 15 Rangers were subleased from PEPCO. Some were leased directly from GSA. PEPCO also leased EVs to other Federal fleets (Grand Canyon and Gettysburg) not within their service territory.

An additional 14 EVs were also leased within the SDGE service territory. However, seven of the leases were to a Navy Fleet that already had EV S-10's and the author believes that they did not participate in the Loaner Program. The other seven EV leases may have been a result of the Loaner Program activities. So, for the sake of argument, it will be assumed that 22 vehicles were leased as a direct result of Loaner Program activities.

The success of the Loaner Program should be judged based on the number of vehicles that have been leased by Federal fleets as a direct result of their participation in the Loaner Program. If this criterion is used to gauge success, then the cost to achieve such success should be understood. Based on a generated lease rate of 22 vehicles, the cost per vehicle lease has been about $\$ 9,800$. That is, for every $\$ 9,800$ that DOE has spent on the Loaner Program, one vehicle has been leased. If it is assumed that the utilities provided support that roughly matched DOE's costs, then the total Loaner Program cost to generate a single lease has been $\$ 19,500$ per vehicle.

(As part of their Incremental Funding Program activities, personnel from the INEEL were able to encourage Ford to provide their own loaner EV Rangers to Federal fleets that were interested in leasing EV Rangers. Any vehicle loans that resulted from the INEEL-specific activities should be credited to Incremental Funding Program activities.) 


\section{CONCLUSIONS}

At the inception of the Loaner Program, most of the domestic OEMs were making electric vehicles available (in at least one state) for either lease or sale. However, by the end of the first year of the Loaner Program, only a single OEM was still accepting vehicle orders and it was taking upwards of a year or more to obtain the vehicles. Given this availability issue, most of the utilities recognized that there is no sense in loaning vehicles and then telling the Federal Fleets that no vehicles are available in a timely manner.

While it is easy to suggest that the legal issue of indemnification should be eliminated, DOE does not have the power to solve this issue for other federal agencies or for the utilities.

While all of the electric utilities were very cooperative and responsive, some of the utilities were unable to overcome their own internal legal bureaucracies when it came to individual agreements with federal agencies. PEPCO's ability to minimize or even eliminate "contractual issues" seemed to be the significant reason why they were able to make so many vehicle loaners (plus being located in Washington, DC). Thus, they had the most success supporting the ultimate objective, which is increasing the leasing and use of electric vehicles by federal agencies.

Given the number of leases generated, the cost to generate the leases, and the difficulty involved in obtaining new vehicles, another National Loaner Program should not be attempted until suitable vehicles will be available in large numbers and in a timely manner. 


\section{Appendix A}

Tables A1 through A6 provide the locations, amount of time, number of vehicles, number of drivers, and miles driven, for each Federal fleet that participated in the Loaner Program. The information is provided by the participating utilities.

Tables A7 through A10 provide drivers' reactions, obstacles the utilities encountered, and comments that the utilities provided.

Table A1. Boston Edison Loaner Program activity.

\begin{tabular}{|c|c|c|c|c|c|c|}
\hline Agency Name & City & State & Dates Loaned & $\begin{array}{c}\text { No. of } \\
\text { Vehicles }\end{array}$ & $\begin{array}{l}\text { No. of } \\
\text { Drivers }\end{array}$ & Miles \\
\hline Longfellow Olmstead Park & Brookline & MA & Apr 99 - Jul 99 & 1 & 5 & 1,220 \\
\hline National Historical Park & Charleston & MA & Apr 99 - Dec 99 & 1 & 3 & 2,210 \\
\hline Coast Guard & Boston & MA & Apr 99 - Jul 99 & 1 & 4 & 360 \\
\hline $\begin{array}{l}\text { Department of Transportation } \\
\text { (VOLPE) }\end{array}$ & Cambridge & MA & Aug 99 - Dec 99 & 1 & 11 & 1,400 \\
\hline $\begin{array}{l}\text { Environmental Protection } \\
\text { Agency }\end{array}$ & Boston & MA & Aug 99 - Dec 99 & 1 & 2 & 275 \\
\hline $\begin{array}{l}\text { Fish and Wildlife (Fish } \\
\text { Hatchery) }\end{array}$ & $\begin{array}{l}\text { North } \\
\text { Attleboro }\end{array}$ & MA & Dec 99-Mar 00 & 1 & 4 & 250 \\
\hline $\begin{array}{l}\text { Fish and Wildlife (Great } \\
\text { Meadows Wildlife) }\end{array}$ & Sudbury & MA & Dec 99-Mar 00 & 1 & 2 & 250 \\
\hline \multirow[t]{2}{*}{$\begin{array}{l}\text { Fish and Wildlife (Parker } \\
\text { River Reservation) }\end{array}$} & Newburyport & MA & Dec 99-Mar 00 & 1 & 4 & 100 \\
\hline & & & Total Reported & 8 & 35 & 6,065 \\
\hline
\end{tabular}


Table A2. Georgia Power Loaner Program activity.

\begin{tabular}{|c|c|c|c|c|c|c|}
\hline Agency Name & City & State & Dates Loaned & $\begin{array}{c}\text { No. of } \\
\text { Vehicles }\end{array}$ & $\begin{array}{l}\text { No. of } \\
\text { Drivers }\end{array}$ & Miles \\
\hline $\begin{array}{l}\text { Environmental Protection } \\
\text { Agency }\end{array}$ & Atlanta & GA & Jun 99 - Aug 99 & 2 & & 350 \\
\hline \multirow{2}{*}{$\begin{array}{l}\text { Environmental Protection } \\
\text { Agency }\end{array}$} & \multirow[t]{2}{*}{ Atlanta } & \multirow[t]{2}{*}{ GA } & \multirow[t]{2}{*}{ Aug 99 - Sep 99} & 1 & 3 & 67 \\
\hline & & & & 1 & 19 & 210 \\
\hline $\begin{array}{l}\text { Federal Highway } \\
\text { Administration }\end{array}$ & Atlanta & GA & Aug 99 - Sep 99 & 1 & 10 & 157 \\
\hline $\begin{array}{l}\text { Kennesaw Mountain } \\
\text { National Battlefield }\end{array}$ & Kennesaw & GA & Dec 99 - Present & 1 & 4 & 50 \\
\hline $\begin{array}{l}\text { Chickamauga National } \\
\text { Battlefield }\end{array}$ & Ft. Oglethorpe & GA & April 2000 & 1 & 4 & 175 \\
\hline $\begin{array}{l}\text { Cumberland National } \\
\text { Seashore }\end{array}$ & St. Marys & GA & January -April & 1 & 5 & 300 \\
\hline $\begin{array}{l}\text { Andersonville National } \\
\text { Historic Site }\end{array}$ & Andersonville & GA & March -April & 1 & 4 & 285 \\
\hline \multirow[t]{2}{*}{ Department of the Interior } & Atlanta & GA & February - April & 1 & 5 & 267 \\
\hline & & & Total Reported & 10 & 54 & 1,861 \\
\hline
\end{tabular}


Table A3. Potomac Electric Power Company Loaner Program activity.

\begin{tabular}{|c|c|c|c|c|c|c|}
\hline Agency Name & City & State & Dates Loaned & $\begin{array}{c}\text { No. of } \\
\text { Vehicles }\end{array}$ & $\begin{array}{c}\text { No. of } \\
\text { Drivers }\end{array}$ & Miles \\
\hline White House & Washington & DC & Sep 98 - Oct 98 & 1 & 1 & \\
\hline U.S. Senate & Washington & DC & Nov 98 - Feb 99 & 1 & 1 & \\
\hline $\begin{array}{l}\text { Environmental Protection } \\
\text { Agency }\end{array}$ & Washington & DC & Sep 98 - Oct 98 & 1 & 1 & \\
\hline $\begin{array}{l}\text { Environmental Protection } \\
\text { Agency }\end{array}$ & Crystal City & VA & May 99 - Dec 99 & 1 & 2 & 3,509 \\
\hline Department of Energy - HQ & Washington & VA & Sep 98 - Oct 98 & 1 & 1 & \\
\hline $\begin{array}{l}\text { Department of Energy - } \\
\text { Germantown }\end{array}$ & Germantown & MD & May 99 - Dec 99 & 1 & 4 & 2,904 \\
\hline \multirow[t]{2}{*}{ Department of Transportation } & Washington & $\mathrm{DC}$ & Sep 98 - Oct 98 & 1 & 1 & \\
\hline & & & May 99 - Jul 99 & 1 & 1 & \\
\hline $\begin{array}{l}\text { Department of Interior at } \\
\text { Patuxent Wildlife Refuge } \\
\text { Center }\end{array}$ & Laurel & MD & Nov 98 - Dec 99 & 1 & 13 & 3,402 \\
\hline $\begin{array}{l}\text { Department of Interior at Rock } \\
\text { Creek Park }\end{array}$ & Washington & $\mathrm{DC}$ & Nov 98 - Apr 99 & 1 & 1 & \\
\hline $\begin{array}{l}\text { Department of Interior at Rock } \\
\text { Creek Park }\end{array}$ & Washington & $\mathrm{DC}$ & Jul 99 - Dec 99 & 1 & 6 & 4,638 \\
\hline $\begin{array}{l}\text { National Institute of Standards } \\
\& \text { Technology }\end{array}$ & Bethesda & MD & Mar 99 - Apr 99 & 1 & 1 & \\
\hline Smithsonian & Washington & $\mathrm{DC}$ & Sep 98 - Oct 98 & 1 & 3 & \\
\hline Smithsonian & Washington & $\mathrm{DC}$ & Mar 99 - Apr 99 & 1 & 1 & \\
\hline Architect of the Capital & Washington & $\mathrm{DC}$ & Nov 98 - Jan 99 & 1 & 1 & \\
\hline $\begin{array}{l}\text { General Services } \\
\text { Administration Headquarters }\end{array}$ & Washington & $\mathrm{DC}$ & Apr 99 - Dec 99 & 1 & 4 & 3,368 \\
\hline National Security Agency & Fort Meade & MD & Nov 98 - Feb 99 & 1 & 1 & \\
\hline Marine Corps & Quantico & VA & Nov 98 - Feb 99 & 1 & 1 & \\
\hline \multirow[t]{2}{*}{ National Institute of Health } & Bethesda & MD & Mar 99 - Apr 99 & 1 & 1 & \\
\hline & & & Total Reported & 19 & 45 & 17,821 \\
\hline
\end{tabular}


Table A4. San Diego Gas and Electric Loaner Program activity.

\begin{tabular}{llclccc}
\hline Agency Name & City & State & Dates Loaned & $\begin{array}{c}\text { No. of } \\
\text { Vehicles }\end{array}$ & $\begin{array}{c}\text { No. of } \\
\text { Drivers }\end{array}$ & Miles \\
\hline $\begin{array}{l}\text { NAVY }-32^{\text {nd }} \text { St. } \\
\begin{array}{l}\text { Transportation } \\
\text { Department }\end{array}\end{array}$ & San & CA & Aug 99-Sep 99 & 1 & & \\
$\begin{array}{l}\text { Navy }-32^{\text {nd }} \text { St. Utilities } \\
\text { Department }\end{array}$ & San & CA & Sep 99-Dec 99 & 1 & 4 & \\
\hline & Diego & & & & & \\
\hline
\end{tabular}

Table A5. Southern California Edison Loaner Program activity.

\begin{tabular}{llclccc}
\hline & & & & No. of & No. of & \\
Agency Name & City & State & Dates Loaned & Vehicles & Drivers & Miles \\
\hline Border Patrol & Temecula & CA & Jun 99-Sep 99 & 1 & 4 & 1,118 \\
Marine Corp Base 29 Palms & 29 Palms & CA & Dec 99- Feb 00 & 1 & & \\
\hline & & & Total Reported & 2 & 4 & 1,118 \\
\hline
\end{tabular}

Table A6. Virginia Power Loaner Program activity.

\begin{tabular}{|c|c|c|c|c|c|c|}
\hline Agency Name & City & State & Dates Loaned & $\begin{array}{c}\text { No. of } \\
\text { Vehicles }\end{array}$ & $\begin{array}{l}\text { No. of } \\
\text { Drivers }\end{array}$ & Miles \\
\hline Fort Monroe & Hampton & VA & Jun 99 - Dec 99 & 1 & 12 & \\
\hline Fort Eustis & $\begin{array}{l}\text { Newport } \\
\text { News }\end{array}$ & VA & Jun 99 - Dec 99 & 1 & 12 & \\
\hline NSGA Northwest & $\begin{array}{l}\text { Great } \\
\text { Bridge }\end{array}$ & VA & Sep 99 - Dec 99 & 1 & 12 & \\
\hline Quantico & Quantico & VA & Oct 99 - Dec 99 & 1 & Many & \\
\hline \multirow[t]{2}{*}{ Fort Lee } & Hopewell & VA & $\begin{array}{l}\text { Nov } 99-\text { Dec } \\
99\end{array}$ & 1 & Many & \\
\hline & & & Total Reported & 5 & $36++$ & \\
\hline
\end{tabular}


Table A7. Federal fleets gave these reasons for not leasing EVs (not listed in any particular order).

- Costs are too high.

- Auxiliary batteries are not strong enough to jump-start multiple cars.

- Range between charges is not far enough.

- Uncomfortable with the range and technology.

- Prefer sedans.

- An unwillingness to "take the risk". It seems the Fleet Manager will take the blame if a procured vehicle does not work out.

- For the EPA in Atlanta, range is an issue, and other internal issues are preventing them from leasing electric vehicles.

Table A8. Federal fleet drivers gave these reactions after driving the loaner vehicles (not listed in any particular order).

- Drivers do not want to give the loaner vehicle back when the loan period is up.

- The stiff suspension took some time getting use to.

- The distance between charges is not far enough.

- The loaner vehicle works just like a gas-powered pickup, only better.

- They were amazed at the cruising speed and acceleration.

- Most are pleased with the experience, but are somewhat afraid of the range.

- Vehicles are being driven everyday and there have been no mechanical problems.

- The drivers find the electric vehicles super clean and quiet. These are two very important attributes for the U.S. Fish and Wildlife.

- All are surprised at the acceleration and cruising speed.

- Vehicle is well liked; range is still a small issue for some of the drivers. 
Table A9. The utilities encountered a variety of obstacles when trying to loan EVs to the Federal fleets. The utilities had the following comments about some of the Federal fleets (not listed in any particular order).

- Unwillingness to indemnify the utility company for liability.

- Very slow in getting a response from management.

- Very long time in having a simple 220-Volt outside plug installed at a parking site.

- Too many different people being involved from the Agency (no one in charge).

- Hurry up and wait attitude.

- Very slow in reviewing and/or approving the loaner agreement.

- Lots of time spent with legal staff questioning the agreements for the loaner and leases vehicles.

- Only 480-volt power was available, 480 / 120 - 208-volt transformers had to be installed.

- There is still a need for more public charging.

- Lack of familiarity with electric vehicles.

- Contract approval on the Federal level takes too long.

- U.S. Military branches are not responding to the offer.

- U.S. Post office is not responding to the offer.

- Contracts are taking way too long.

- Lack of knowledge of the technology.

- Because one utility utilizes utility fleet vehicles for the loan program, the receiving party must sign a Loan Agreement Contract. This has proven to be very challenging when dealing with federal agencies.

- The Federal fleets do not have any repercussions if they do not choose to purchase or lease alt fuel vehicles. No fines, no real harm if they choose not to follow the order.

- The range between charges is too short. They would buy one in a minute if reliably were $100+$ miles under real world driving conditions.

- Contract approval by lawyers is very slow. 
- Until we have vehicles with NiMH batteries available here in the Northeast, it is going to be a tough sell. More vehicle varieties and advanced batteries will solve all the problems associated with interest in leasing by just about all the agencies.

- Price and charging availability.

- It has been a "reeducation" process in introducing electric vehicles into the fleets. The existing way of thinking is internal combustion engines (ICE) are best and nothing compares, so we try to discuss alternatives, and explain while electric vehicles can't replace all ICE vehicles, there is an opportunity for a mix of technologies to do the job.

- There is no down side if they do not lease the vehicle.

- There is a fear of the new technology is an obstacle.

- Range, price, no teeth to the law. 
Table A10. Comments some of the utilities had about the vehicles leased for the Loaner Program (not listed in any particular order).

- One of Boston Edison's vehicles died at a tollbooth. It turned out to be failed component in the controller.

- One of Boston Edison's vehicles had a flashing wrench on dashboard, turned out to be several problems... The charge module under hood needed to be replaced, and the battery pack also needed to be replaced. This took 2 weeks to fix.

- Some vehicles have had bad on-board chargers. Each of PEPCO's vehicles has had the charger replaced at least once. Some have had $2^{\text {nd }}$ replacements.

- $\quad$ Each PEPCO vehicle had to have its battery pack replaced.

- Some of PEPCO's vehicles have had to have the battery control module replaced.

- Each PEPCO vehicle has had to have the IAA module replaced.

- The EV was used when the batteries needed to be levelized. As a result the vehicle went into limp home mode. After full charge it worked fine.

- Fuel fired heater did not work in super cold weather. Diesel fuel seemed to gel.

- One of the EVs at Georgia Power had a battery problem with the pack. It has been pulled back from the customer and a replacement vehicle is now in their hands. This was a bad way to start out the test, but I am keeping tabs on them making sure they are still using the replacement vehicle.

- PEPCO has experienced problems with batteries and on board chargers.

- Everyone is experiencing slow delivery of new vehicles.

- The S-10s were all pulled back for the recall by GM and the Fords still have some minor software glitches. 